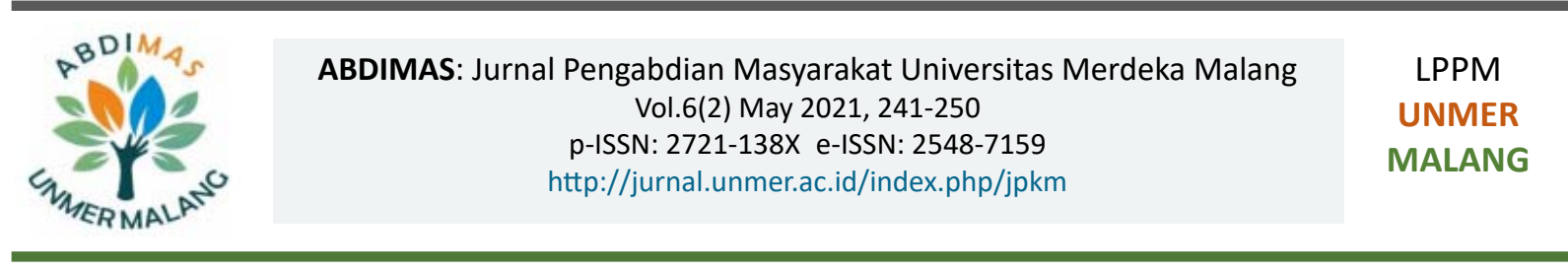

\title{
Pengawetan dan Pemberian Nilai Tambah Produk Jamur Tiram Putih Menjadi Sate dan Bakso Jamur
}

\author{
Agus Sugianto, Anis Sholihah \\ Departemen Agroteknologi, Fakultas Pertanian, Universitas Islam Malang \\ Jl. Mayjen Haryono No.193, Malang, 65144
}

\author{
ARTICLE INFO \\ Received: 2020-12-17 \\ Revised: 2021-01-23 \\ Accepted: 2021-02-21
}

\begin{abstract}
The unsolved problem of mushroom farmers in Blayu village is post-harvest handling and adding value to mushroom fruit bodies, if the harvest is high, many farmers experience losses because they cannot store more than 7 days. The service was carried out in Blayu village, Wajak, Malang Regency, divided into six stages: (1). Program socialization to farmer groups; (2). Post-harvest technology extension; (3). Training and mentoring of mushroom fruit preservation technology, (4). Training and assistance in making mushroom-based fast food, (5) Procurement of infrastructure, (6) Monitoring, evaluation and reporting. The results of the service program can be concluded: 1). The mushroom farmers in the Guyub Makmur farmer group have mastered the technology of preserving white oyster mushrooms, reaching 90\%; 2). Preservatives and ingredients and accessories, storage tools, tools for making mushroom meatballs and mushroom satay are available; 3). 100\% of farmer groups can make satay and mushroom meatballs and start a business selling mushroom meatballs, the income of farmer groups increases between 55\% - 65\% compared to before; 4). An IPR has been produced entitled "Mushroom Storage Model and Postharvest Management with the recording number from the Director General of IPR 000187424".
\end{abstract}

(C)2021 Published by University of Merdeka Malang. This is an open access article distributed under the CC BY-SA 4.0 license (https://creativecommons.org/licenses/by-sa/4.0/)

How to cite: Sugianto, A., \& Sholihah, A. (2021). Pengawetan dan Pemberian Nilai Tambah Produk Jamur Tiram Putih Menjadi Sate dan Bakso Jamur. Abdimas: Jurnal Pengabdian Masyarakat Universitas Merdeka Malang, 6(2), 241-250. https://doi.org/10.26905/abdimas.v6i2.5174

\section{PENDAHULUAN}

Berdasarkan dokumen dari Desa Blayu, Kecamatan Wajak, Kabupaten Malang tahun 2010-2015, desa ini secara struktural merupakan bagian integral yang tak terpisahkan dari sistem perwilayahan Kecamatan Wajak. Secara geografis Desa Blayu terletak pada wilayah timur jalur alternatif transportasi timur, dengan luas 378 hektar yang terbagi menjadi tiga dusun, yakni Dusun Krajan, Dusun Pijetan, dan Dusun Sumbersuko dengan perbatasan wilayah sebelah utara adalah Desa Wajak, sebelah barat adalah Desa Sukolilo, sebelah selatan adalah Desa Codo dan sebelah timur adalah Desa Patokpicis. 
ABDIMAS: Jurnal Pengabdian Masyarakat Universitas Merdeka Malang

Volume 6, No. 2, May 2021: 241-250

Jumlah penduduk Desa Blayu adalah 10.876 jiwa yang terdiri dari 3.812 jiwa laki-laki dan 7.064 jiwa perempuan. Sektor perekonomiannya didominasi oleh sistem pertanian dengan model budidayanya masih tradisional (mulai dari pengolahan lahan sampai pemilihan komoditas produk pertaniaanya). Komoditas utama yang diusahakan belum bervariasi, hal ini diakibatkan adanya sistem pengairan yang tidak bagus. Oleh sebab itu, dalam mengatasi persoalan tersebut, program pembangunan desa diarahkan pada perbaikan sistem irigasi, penggunaan teknologi tepat guna, perbaikan pola tanam, dan pemilihan komuditas alternatif yang memungkinkan untuk dikembangkan di Desa Blayu (Profil Desa Blayu, 2018). Guna menekan kondisi banyaknya penganguran di usia produktif maka salah satu program Desa Blayu adalah mengembangkan budidaya jamur kayu. Dari sini harapannya dapat meningkatkan perokonomian sekaligus menciptakan lapangan kerja baru bagi masyarakat.

Sudah hampir lima tahun komoditas alternatif yang telah diusahakan oleh masyarakat Blayu adalah budidaya jamur tiram putih dengan menggunakan sistem semi modern (dalam bentuk bag-log). Kesungguhan dalam berwirausaha jamur ditunjukkan dengan terbentuknya kelompok-kelompok petani jamur yang terus berkembang hingga saat ini.

Suhu lingkungan di Desa Blayu sangat mendukung untuk budidaya jamur tiram putih. Faktor ini dapat mempengaruhi pertumbuhan jamur tiram tersebut. Daerah dengan suhu ekstrem yaitu suhu yang terletak di bawah suhu minimum dan di atas suhu maksimum dapat menyebabkan jamur tiram putih tidak mampu tumbuh. Sedangkan di antara suhu minimum dan maksimum terdapat suhu optimum yaitu suhu yang menyebabkan jamur dapat tumbuh dan berkembang dengan harga efisiensi biologi tertinggi. Suhu ekstrem sangat berpengaruh pada sebaran strain atau spesies jamur, sehingga masingmasing strain memiliki pola distribusi yang spesifik (Alananbeh et al., 2014).

Terbentuknya kelompok petani jamur di Desa Blayu sangat membuka peluang untuk mengembangkan usaha yang lebih besar, sehingga mampu meningkatkan daya beli masyarakat, meningkatkan perekonomian, dan memperbaiki kualitas hidup masyarakat yang berdampak terhadap pembangunan pedesaan. Budidaya jamur tiram putih tergantung dari faktor antara lain: komposisi substrat tanam, keadaan lingkungan, kualitas bibit, berat substrat, dan nilai Efisiensi Biologi (EB). Substrat tanaman jamur yang berkualitas harus mampu diubah menjadi badan buah oleh jamur yang diinokulasikan. Efisiensi biologi (EB) yang tinggi mengindikasikan bahwa substrat tanam (serbuk gergaji) berhasil dikonversi oleh jamur tiram menjadi badan buah segar. Kualitas bibit ditentukan oleh metode pembuatannya, karena miselium yang dihasilkan berkaitan dengan kemampuan mendegradasi serat dalam substrat (Sugianto et al., 2017).

Kelompok petani jamur tiram yang ada di tiga dusun yaitu Krajan, Pijetan, dan Sumbersuko, belum memiliki inovasi atau semangat untuk mengembangkan usahanya. Pengembangan manajemen masih menggunakan pola tradisional yang dapat dibagi menjadi tiga bagian yaitu pengadaan bahan baku, pembuatan substrat, dan panenan. Manajemen keuangan yang menyangkut pencatatan keuntungan hampir tidak pernah dilakukan. Dampaknya pada akses untuk peminjaman modal dari pihak perbankan tidak pernah disetujui sehingga selama terbentuknya kelompok jamur tiram tersebut semua modal berasal dari swadaya kelompok itu sendiri. 
Pada penentuan permasalahan prioritas dari kelompok tani yang berasal dari Krajan dan Sumbersuko yang telah disepakati adalah permasalahan pascapanen dan pemberian nilai tambah terhadap badan buah jamur yang telah dipanen oleh kelompok tani jamur di Desa Blayu, sehingga pendapatan yang diperoleh petani selama ini hanya berasal dari badan buah jamur segar yang dipanen. Jika terjadi panen raya jamur, banyak petani yang mengalami kerugian karena tidak dapat menyimpan jamurnya dalam waktu lebih dari 7 hari. Kerusakan badan buah jamur terjadi karena proses kelayuan dan perubahan warna menjadi coklat akibat adanya reaksi enzimatis karena bereaksi dengan oksigen. Pencegahannya hanya dapat dilakukan dengan penanganan pascapanen yaitu melalui teknologi pengawetan. Usaha pemberian nilai tambah pada badan buah jamur yang diolah menjadi makanan siap saji selama ini belum pernah dilakukan secara profesional padahal hal ini akan mampu meningkatkan pendapatan petani jauh lebih besar dibanding yang telah diterima hingga saat ini. Tujuan kegiatan pengabdian ini adalah untuk memecahkan masalah panen raya jamur pada kelompok petani Guyub Makmur yaitu cara penanganan pascapanen dan pemberian nilai tambah badan buah jamur agar pendapatan petani dapat bertambah. Prioritas permasalahan mitra dari kelompok petani dari Krajan dan Sumbersuko yang telah ditentukan disampaikan oleh ketua kelompoknya adalah: (1) Permasalahan penanganan pascapanen dan pemberian nilai tambah terhadap badan buah jamur yang telah dipanen, sehingga pendapatannya dapat ditingkatkan karena selama ini petani hanya memperoleh dari penjualan badan buah jamur segar yang dipanen; (2) Jika terjadi panen raya jamur, banyak petani yang mengalami kerugian karena tidak dapat menyimpan jamurnya lebih dari 7 hari. Kerusakan badan buah jamur terjadi karena proses kelayuan dan perubahan warna menjadi coklat akibat adanya reaksi enzimatis karena bereaksi dengan oksigen. Solusi dari permasalahan tersebut hanya dengan penanganan pascapanen yaitu melalui teknologi pengawetan. Usaha pemberian nilai tambah pada badan buah jamur yang diolah menjadi makanan siap saji selama ini belum pernah dilakukan secara professional padahal hal ini akan mampu meningkatkan pendapatan petani jauh lebih besar dibanding yang telah diterima hingga saat ini.

Program pengabdian masyarakat ini bertujuan untuk memberikan pelatihan dan pendampingan bagi kelompok petani jamur sehingga dapat menciptakan produk jamur yang dapat memiliki nilai tambah dan meningkatkan pendapatan para petani.

\section{METODE}

Metode yang digunakan pada program ini adalah kualitatif dan kuantitatif. Untuk kualitatif dengan mengadakan observasi partisipatif. Pelaksanaan kegiatan dilakukan dengan tahap-tahap sebagai berikut: (1) Sosialisasi program pada kelompok tani; (2) Penyuluhan teknologi pascapanen; (3) Pelatihan dan pendampingan teknologi pengawetan badan buah jamur; (4) Pelatihan dan pendampingan pembuatan makanan cepat saji berbasis jamur dan pemasarannya, (5) Pengadaan sarana-prasarana dan penyediaan tempat khusus untuk pengawetan badan buah jamur tiram putih dan dapur mini sebagai tempat bagi kelompok tani Guyub Makmur untuk pembuatan makanan siap saji; (6) Monitoring, evaluasi dan pelaporan. Tahap evaluasi dilaksanakan guna mengetahui dampak dan manfaat dari kegiatan dengan menggunakan teknik wawancara. Pengabdian ini dilaksanakan di Desa Blayu, Kecamatan Wajak, 
ABDIMAS: Jurnal Pengabdian Masyarakat Universitas Merdeka Malang

Volume 6, No. 2, May 2021: 241-250

Kabupaten Malang mulai September 2019-April 2020. Tahap-tahap pelaksanaan program sebagaimana disajikan pada Gambar 1.

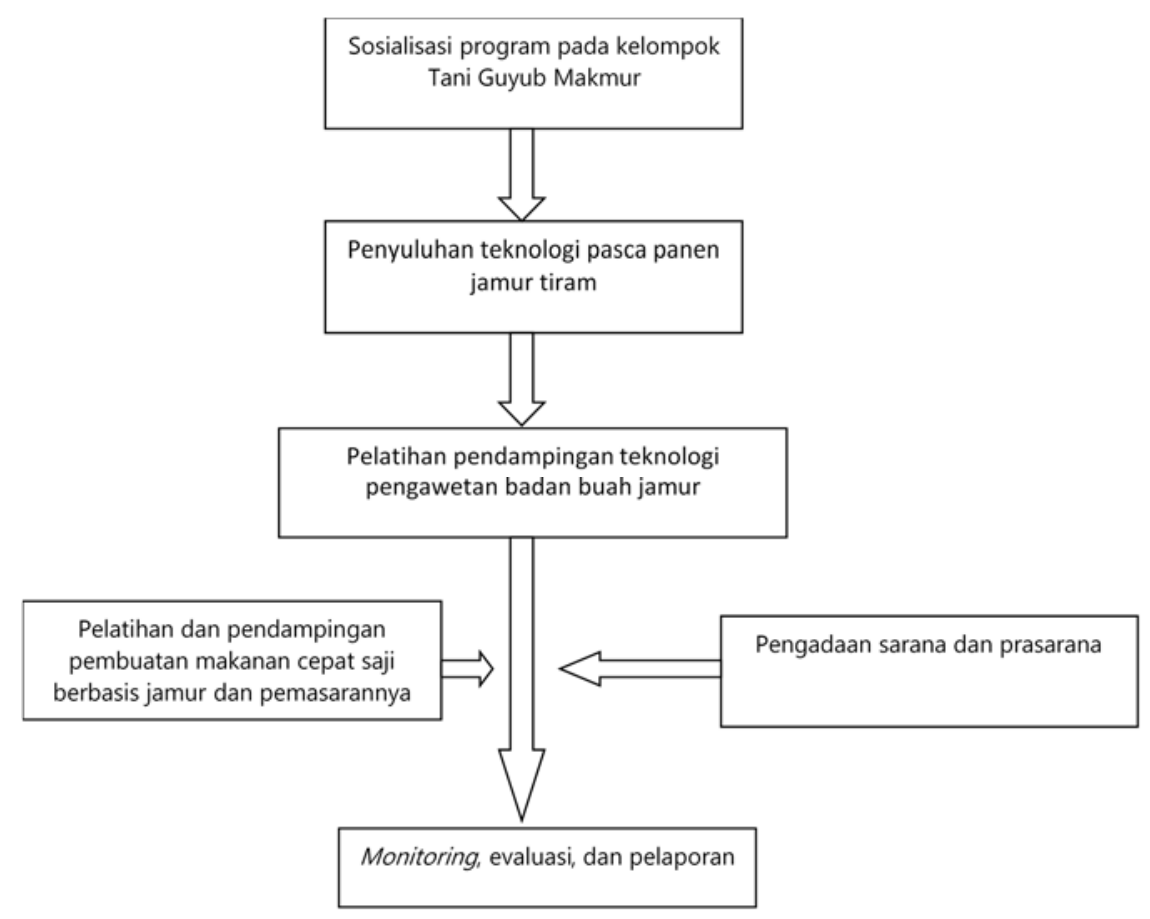

Gambar 1. Tahap-tahap pelaksanaan program pengawetan dan pemberian nilai tambah produk jamur tiram putih menjadi sate dan bakso jamur

Teknik pengumpulan data yang digunakan dengan checklist dalam bentuk skor dari masingmasing peserta pelatihan dengan membandingkan hasil pelatihan pra-pelatihan dan setelah pelatihan berlangsung. Data yang diperoleh dianalisis dalam bentuk deskriptif yang dibuat dalam bentuk persentase.

\section{HASIL DAN PEMBAHASAN}

\section{Pengawetan jamur tiram}

Pelatihan pengawetan badan buah jamur pada kelompok tani Guyub Makmur diikuti oleh seluruh anggotanya sebanyak 10 orang. Bahan-bahan yang dipakai dalam praktek diantaranya adalah jamur tiram, larutan $\mathrm{CaCl}_{2}$ 1\% Asam askorbat, Asam sitrat, garam, kunyit, Natrium metabisulfi, Kalsium karbonat, air. Berikut tahapan pengawetan: (1) Tahap persiapan meliputi penyotiran, pencucian dengan air, perendaman dengan larutan $\mathrm{CaCl}_{2}$ 1\% dan dilanjutkan blansir dengan air panas; (2) Proses sortasi berfungsi untuk memisahkan jamur tiram putih yang baik dengan yang kurang baik kualitasnya; (3) Pencucian pendahuluan jamur tiram putih bertujuan untuk memisahkan kotoran (sisa media budidaya) dan mengurangi jumlah mikroba awal; (4) Setelah tahap sortasi dan pencucian jamur tiram putih direndam dengan $\mathrm{CaCl}_{2} 1 \%$ dalam waktu 1 menit. Perendaman dalam larutan $\mathrm{CaCl}_{2}$ 1\% berfungsi untuk 
membunuh mikroba yang ada pada sampel jamur tiram putih; (5) Jamur selanjutnya diblansir dengan air panas $\left(80-100^{\circ} \mathrm{C}\right)$ dalam waktu 1 menit berfungsi untuk mematikan mikroba yang mungkin masih tersisa setelah proses perendaman dalam larutan $\mathrm{CaCl}_{2}$ 1\%; (6) Penyimpanan dalam larutan aditif berfungsi untuk memperpanjang waktu simpan sampel jamur tiram putih. Larutan aditif yang digunakan sebagai larutan penyimpan jamur tiram putih yaitu: (1) Asam askorbat 0,05\%; (2) Asam sitrat 1\%; (3) Garam 2\%; dan (4) Kunyit 1\%. Hasil yang baik untuk menghambat perkembangan jamur mikroskopik dan bakteri mampu dihambat dengan menggunakan asam sitrat $1 \%$. Di samping itu, performa jamur tidak banyak mengalami perubahan (Anggarani \& Rusijono, 2015).

Perbandingan antara jamur segar yang dibiarkan dengan yang diawetkan bahwa pembiaran dalam waktu 6 sampai 8 jam. Akibat dari efek tersebut memicu terjadinya pencoklatan enzimatis (browning) pada jamur walaupun reaksinya lambat (Annisa et al., 2017).

Berdasarkan hasil evaluasi bahwa sebelum dilaksanakan penyuluhan, anggota kelompok yang berjumlah sejumlah 10 orang tidak memahami cara pengewetan $(0 \%)$, tetapi setelah pelatihan dilaksanakan, menghasilkan 9 peserta dengan penilaian sangat baik (90\%). Terlihat peningkatan pengetahuan pada masyarakat anggota kelompok tani, sehingga diharapkan mampu memperpanjang daya simpan jamur tiram saat menghadapi panen raya.

\section{Bakso jamur dan sate jamur tiram putih}

Pelatihan pembuatan makanan berbasis jamur bertujuan untuk melatih kelompok tani dalam mengelola jamur tiram putih agar tidak terbuang saat terjadi panen raya. Materi pelatihan meliputi pembuatan bakso jamur dan sate jamur yang dilatih oleh pelatih yang berpengalaman yaitu Ibu Jamilah. Hasil dari pelatihan dari 10 orang yang telah melakukan praktek dan dinilai oleh tenaga ahlinya ternyata semuanya memenuhi syarat (100\%) dan dianggap layak untuk dibuat usaha sampingan.

Diversifikasi produk pangan merupakan salah satu upaya penganekaragaman pangan yang tidak hanya tergantung pada satu jenis produk pangan, tetapi terdapat keragaman atau variasi bahan pangan yang digunakan sebagai pilihan. Diversifikasi pangan menyangkut aspek produksi, konsumsi, pemasaran, dan distribusi. Adanya diversifikasi pangan dapat meningkatkan kualitas sumber daya manusia (SDM), pembangunan pertanian di bidang pangan, dan perbaikan gizi masyarakat.

Salah satu kandungan jamur tiram yang menjadi perhatian adalah dari segi protein dan seratnya dimana protein jamur tiram hampir setara dengan protein yang terkandung dalam daging ayam. Menurut (Muchtadi, 2010), menyatakan bahwa kandungan protein jamur tiram adalah sebesar 17,5\%, sedangkan seratnya sebesar 8,0\%. Berdasarkan program yang dilakukan oleh Saragih (2015), kandungan serat yang terdapat pada jamur tiram $48 \%$ dapat memenuhi kebutuhan serat pangan/orang/hari. Serat yang terkandung pada jamur sangat baik untuk melancarkan pencernaan dan cocok untuk program diet. Selain kandungan protein yang hampir menyerupai daging ayam, tekstur dan rasa dari jamur tiram juga menyerupai daging. Salah satu kekurangan yang dimiliki jamur tiram adalah sifatnya yang mudah rusak atau tidak tahan lama. Oleh karena itu, pengolahan yang dipilih adalah menjadikannya sebagai olahan bakso dan sate. Produk olahan tersebut merupakan salah satu bentuk diversifikasi produk pangan (Sugianto, 2013). 
ABDIMAS: Jurnal Pengabdian Masyarakat Universitas Merdeka Malang

Volume 6, No. 2, May 2021: 241-250

Target capaian dalam pengabdian yang dilaksanakan di kelompok tani Guyub Makmur di Desa Blayu, Wajak, Kabupatan Malang untuk HKI yang berjudul Model Penyimpanan Jamur dan Pengelolaan Pascapanen, sudah tercatat oleh Dirjen HKI dengan Nomer 000187424.

\section{Pembuatan bakso jamur}

Pelatihan pembuatan bakso jamur tiram diikuti oleh anggota kelompok petani Guyub Makmur Desa Blayu, Kecamatan Wajak, Kabupaten Malang sebagai mitra dan pelatihan dilakukan oleh profesional pengembang produk makanan berbahan dasar jamur dari Malang. Proses pembuatan bakso jamur tiram adalah sebagai berikut: (1) Menyiapkan bahan bakso jamur berupa, 500 gram badan buah jamur tiram putih, tepung sagu 1 ons, putih telur 1 butir, lada (disesuaikan), minyak barbeque (disesuaikan), dan garam (disuaikan); (2) Langkah pertama terlebih dahulu meracik adonan bakso jamur dengan cara batang jamur dihaluskan atau diblender dan airnya diperas. Selanjutnya putih telur ditambahkan, kemudian diaduk adonan tersebut secara merata, berikutnya dimasukan tepung sagu, lada, garam, dan juga minyak barbeque, dilakukan pengadukan hingga rata, begitu seluruh adonan telah menyatu, dibuat bentuk bulat-bulat kecil menyerupai bola bekel; (3) Berikutnya membuat kuah bakso, bahan-bahan yang disiapkan antara lain daun bawang 2 batang, bawang putih 3 siung, bawang merah 4 siung, garam, dan lada (disesuaikan). Pembuatan kuah bakso dilakukan dengan terlebih dulu memasak air di dalam panci stenlis. Langkah selanjutnya bumbu-bumbu yang telah disiapkan dihaluskan antara lain bawang merah, bawang putih, dan daun bawang. Berikutnya bumbu yang sudah dihaluskan dimasukan ke dalam air yang telah direbus. Selanjutnya garam dan lada (sesuai kebutuhan) ditambahkan. Kuah dibiarkan mendidih kemudian masukkan bakso jamur yang telah dibentuk bola tadi, dan dididihkan; (4) Berikutnya penyajian dilakukan dengan menyajikan bakso jamur beserta kuahnya caranya dengan menambahkan bahan pelengkapnya seperti mie kuning, bawang goreng, daun seledri, kecap manis, saos, dan sambal. Bakso jamur disajikan pada saat panas atau hangat.
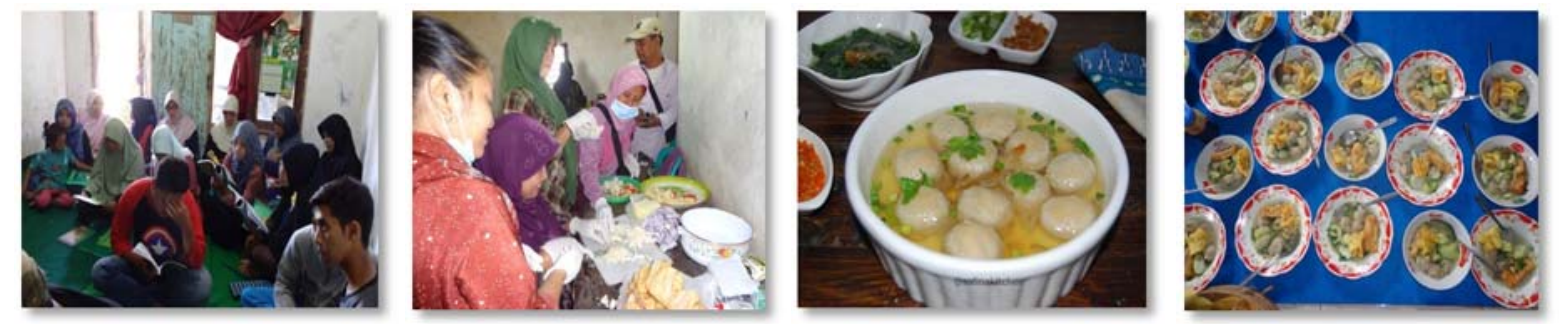

Gambar 2. Proses pelatihan hasil praktik pembuatan bakso jamur tiram putih.

(a) Penyampaian teori kepada peserta pelatihan; (b) Praktik pembuatan bakso jamur tiram putih; (c) Hasil praktik bakso jamur tiram putih; (d) Bakso jamur tiram putih dari peserta pelatihan yang siap dinilai oleh pakar

Target luaran dari kegiatan ini adalah mitra dapat 100\% memahami, membuat, dan memproduksi bakso jamur yang akan dipasarkan dan dijual. Pada pelaksanaan kegiatan pelatihan ini mitra dapat memahami materi pelatihan dan mempraktikan proses produksi dengan baik. 
Inovasi bersumber dari ide yang berasal dari individu yang membentuk sikap kreatif. Sikap ini dapat diajarkan kepada orang lain sehingga dapat membantu orang lain menjadi kreatif pula. Semakin banyak ide atau gagasan yang dimiliki oleh individu, maka proses inovasi akan mudah diterapkan. Nilai jual jamur tiram dapat ditingkatkan dengan membuat produk makanan berbahan dasar jamur tiram, seperti keripik jamur tiram, bakso jamur, stick jamur, serundeng jamur, dan produk jamur lain yang mempunyai nilai tambah (Wariati et al., 2018).

Berdasarkan hasil penilaian oleh pakar, bakso jamur yang dibuat oleh para peserta pelatihan dinyatakan telah memenuhi standar untuk layak dijual. Penilaian didasarkan pada rasa, penampilan, dan kebersihan bakso yang dibuat.

Pengertian dari bakso jamur secara umum adalah bakso yang bahan bakunya terbuat dari jamur tiram, kemudian ditambahkan aneka rempah-rempah sebagai bumbu. Bakso jamur terbilang aman dan sehat untuk dikonsumsi karena terbuat dari bahan-bahan alami tanpa pengawet dan penyedap rasa (De Yusa \& Magdalena, 2015)

\section{Pembuatan sate jamur}

Pelatihan pembuatan sate jamur jamur tiram dilaksanakan pada pelatihan hari ke-2 yang diikuti oleh anggota kelompok petani Guyub Makmur Desa Blayu Kecamatan Wajak, Kabupaten Malang. Proses pembuatan sate jamur tiram sebagai berikut: (1) Menyiapkan bahan sate jamur berupa jamur tiram 200 gram, dicuci hingga bersih kemudian direbus sampai menjadi layu; (2) Menyiapkan bahan bumbu perendam sate jamur berupa 4 buah cabe rawit yang dihaluskan, 1 sendok teh ketumbar yang dihaluskan, 1 butir kemiri yang dihaluskan, 1 sendok makan kecap manis, gula, dan garam disesuaikan; (3) Menyiapkan bahan olesan yang terdiri dari kecap manis 2 sendok makan dan mentega 1 sendok makan; (4) Langkah membuatnya semua bumbu perendam yang disiapkan dicampur, jamur yang layu ditusuk dengan tusuk sate dan diatur sedemikian rupa. Jamur yang sudah diberi tusukan sate diolesi dengan bahan olesan. Selama 30 menit diamkan di dalam kulkas hingga tekturnya berubah. Kemudian jamur diolesi lagi dengan bahan olesan; (5) Sate jamur yang sudah siap dibakar sambil dioles dengan bahan olesan, pemanggangan dilakukan sampai matang. Sate jamur sangat baik disajikan dengan sambal kecap atau sambal kacang dalam keadaan hangat.
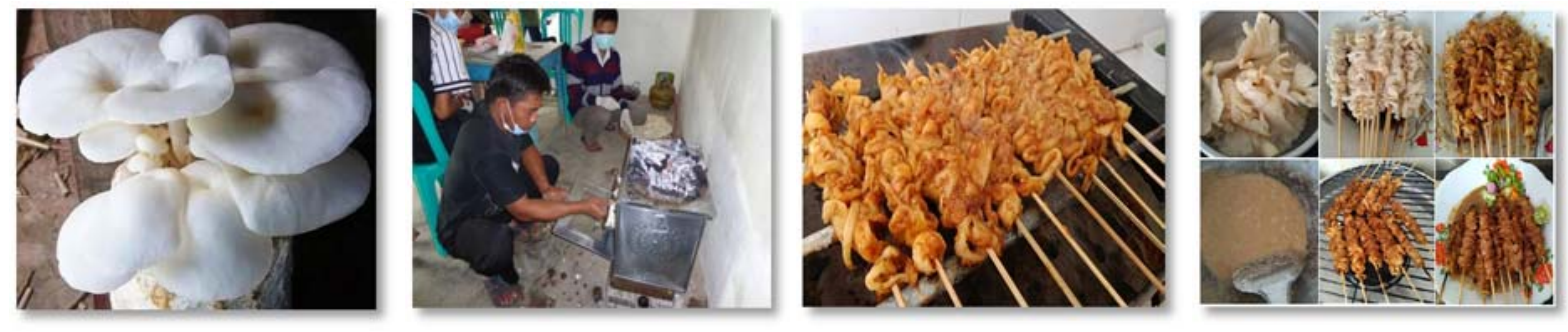

Gambar 3. Proses dan hasil pembuatan sate jamur tiram putih (a) Bahan sate jamur tiram putih; (b) Proses pembuatan sate jamur; (c) Pemanggangan sate jamur tiram;

(d) Urutan proses sate jamur 
ABDIMAS: Jurnal Pengabdian Masyarakat Universitas Merdeka Malang

Volume 6, No. 2, May 2021: 241-250

Target luaran dari kegiatan ini adalah mitra dapat 100\% memahami, membuat, dan memproduksi sate jamur yang akan dipasarkan dan dijual. Pada pelaksanaan kegiatan pelatihan ini mitra dapat memahami materi pelatihan dan mempraktikan proses produksi dengan baik yang masuk dalam ekonomi kreatif.

Gagasan atau ide yang dimiliki individu mampu mendorong terciptanya ekonomi kreatif yang merupakan kegiatan ekonomi yang mampu melahirkan konsep kewirausahaan maupun konsep ekonomi kreatif. Bagi sebagian orang, kreativitas adalah proses berpikir yang dapat melahirkan inspirasi baru yang berbeda dari pada umumnya. Bagi seseorang yang inovatif akan tertantang untuk dapat melahirkan suatu yang baru, baik berupa gagasan maupun karya nyata. Pada dunia bisnis, kreativitas adalah bagaimana upaya menerapkan ide dan gagasan dalam suatu pekerjaan yang menguntungkan (Wariati et al., 2020).

\section{Dampak ekonomis}

Praktik pembuatan sate jamur oleh kelompok tani Guyub Makmur Desa Blayu Wajak, yang semula hanya menjual jamur dalam bentuk jamur segar diharapkan memiliki ide atau gagasan untuk memanfaatkan potensi jamur tiram yang ada agar dapat dijadikan peluang usaha untuk meningkatkan penghasilan dan pengolahan jamur tiram menjadi produk-produk lain yang bernilai jual. Pemilihan pembuatan bakso dan sate jamur disesuaikan dengan kondisi perekonomian masyarakat di Desa Blayu. Daya beli masyarakat yang paling menentukan terhadap produk yang telah diupayakan, sehingga laku untuk dijual dan disukai untuk keberlanjutannya.

Berdasarkan sudut pandang ekonomi, harga per kilogram jamur lebih rendah dibandingkan dengan daging ayam (Ashriyyah, 2015). Oleh sebab itu, keterampilan membuat bakso dan sate sangat cocok dikembangkan menjadi usaha kelompok tani Guyub Makmur. Bakso dan sate jamur harganya lebih rendah dibandingkan dengan bakso dan sate yang dibuat dengan daging sapi atau ayam, dengan demikian konsumen akan memilih yang berbahan dasar jamur.

Melalui pembukaan usaha penjualan bakso jamur dan sate jamur, pendapatan kelompok tani dapat meningkat berkisar antara 55-65\% dibandingkan sebelumnya. Pendapatan rata-rata sebelumnya dari kelompok tani adalah Rp2.500.000,- setelah membuka usaha menjadi Rp3.875.000,- sampai Rp4.125.000,-. Usaha penjualan produk tersebut dilakukan dengan membuka warung bakso dan sate jamur atau saat ada bazar atau saat ada hajatan masyarakat Blayu. Pada acara-acara hajatan besar, anggota kelompok Guyub Makmur bekerja secara keseluruhan dan biasanya sampai menghabiskan jamur $25 \mathrm{~kg}$. Usaha ini berlangsung hingga saat ini dan sebagai keberlajutan program, mereka yang telah mahir membuat bakso dan sate jamur mengajari para generasi muda untuk meningkatkan pengetahuan dan keterampilannya.

\section{SIMPULAN DAN SARAN}

Kegiatan Program Pengabdian kepada Masyarakat ini dapat disimpulkan antara lain: (1) Kelompok petani jamur tiram putih yang tergabung pada kelompok tani Guyub Makmur dapat 
menguasai teknologi pengawetan jamur tiram putih mencapai 90\%; (2) Telah tersedia alat pengawet dan bahannya beserta kelengkapan alat penyimpannya serta tersedia alat untuk membuat bakso jamur dan sate jamur; (3) 100\% anggota kelompok tani Guyub makmur dapat membuat sate dan bakso jamur. Melalui pembukaan usaha penjualan bakso jamur dan sate jamur, pendapatan kelompok tani dapat meningkat berkisar antara 55-65\% dibandingkan sebelumnya; (4) Telah dihasilkan HKI yang berjudul Model Penyimpanan Jamur dan Pengelolaan Pascapanen, sudah tercatat oleh Dirjen HKI dengan Nomer 000187424

Saran kegiatan selanjutnya di Desa Blayu adalah adanya pendampingan yang lebih intensif pada penduduk yang memproduksi olahan bakso dan sate dari jamur minuman sampai mendapatkan PIRT. Bagi pemerintah Desa Blayu, pelatihan ini dapat diteruskan untuk dusun-dusun yang lain sehingga pengetahuan pembuatan nilai tambah terhadap jamur tiram putih dapat dilakukan oleh masyarakat secara luas. Peningkatan pengetahuan dan keterampilan bagi kaum milenial di Desa Blayu sangatlah penting, sehingga mereka tidak selalu berangan-angan menjadi pegawai negeri.

\section{Ucapan Terima Kasih}

Ucapan terima kasih ditujukan kepada Ketua LPPM Unisma, Kepala Desa Blayu-Wajak dan semua pihak yang terlibat dalam kegiatan ini.

\section{DAFTAR PUSTAKA}

Alananbeh, K. M., Bouqellah, N. A., \& Al Kaff, N. S. (2014). Cultivation of oyster mushroom Pleurotus ostreatus on date-palm leaves mixed with other agro-wastes in Saudi Arabia. Saudi Journal of Biological Science, 21(6), 616-625. https://doi.org/10.1016/j.sjbs.2014.08.001

Anggarani, M. A., \& Rusijono, R. (2015). Optimasi pengawetan produk jamur tiram segar sebagai upaya penguatan industri olahan jamur. Jurnal Sains \& Matematika, 3(2), 245-258.

Annisa, N., Sa'ban, F. A., \& Hanidah, I. I. (2017). Diversifikasi produk olahan jamur (Pleurotus ostreatus) sebagai peningkatan pengetahuan keterampilan dalam upaya mendukung hidup sehat: Studi kasus RW 05 Desa Cipacing-Jatinangor. Prosiding Penelitian \& Pengabdian kepada Masyarakat, 4(3), 390-447. https://doi.org/10.24198/jppm.v4i3.18624

Ashriyyah, A. (2015). Eksperimen pembuatan dendeng giling jamur tiram (Pleurotus ostreanus) substitusi ikan lele [Thesis]. Jurusan Pendidikan Kesejahteraan Keluarga, Fakultas Teknik, Universitas Negeri Semarang.

De Yusa, V., \& Magdalena, B. (2015). Pemanfaatan dan pengembangan desa berbasis web dan pengembangan bisnis budidaya jamur tiram menjadi bakso jamur di Pekon Tambah Rejo Kec Gading Rejo Kab Pringsewu. Jurnal Teknologi Informasi dan Bisnis Pengabdian Masyarakat Darmajaya, 1(2), 57-73.

Muchtadi, D. (2010). Teknik Evaluasi Nilai Gizi Protein. Bandung: Alfabeta.

Profil Desa Blayu. (2018). Profil Desa Blayu, Kecamatan Wajak, Kabupaten Malang, Laporan Kerja Tahunan Desa Blayu.

Saragih, R. (2015). Nugget jamur tiram (Pleurotus ostreatus) sebagai alternatif pangan sehat vegetarian. 
ABDIMAS: Jurnal Pengabdian Masyarakat Universitas Merdeka Malang

Volume 6, No. 2, May 2021: 241-250

\section{E-Jurnal WIDYA Kesehatan dan Lingkungan, 1(2), 90-95.}

Sugianto, A. (2013). Teknologi TEL Jamur Tiram Putih untuk Melipatgandakan Produksi. Malang: Aditya Media Publishing.

Sugianto, A., Solihah, A., \& Hartono, P. (2017). Acceleration of five types edibel wood mushroom production through varied harvest synchronization temperature settings. Journal of Agriculture and Environmental Sciences, 6(2), 128-133. https://doi.org/10.15640/jaes.v6n2a15

Wariati, A., Fatonah, S., \& Khoiruman, M. (2020). Pengembangan dan peningkatan nilai tambah budidaya jamur tiram melalui pelatihan sosis jamur kepada Kelompok Wanita Mandiri Desa Gerdu. Wasana Nyata: Jurnal Pengabdian kepada Masyarakat, 4(1), 17-22. https://doi. org/10.36587/wasananyata.v4i1.578

Wariati, A., Wijayanti, A. P., \& Khoiruman, M. (2018). Pengembangan dan peningkatan nilai tambah budidaya jamur tiram melalui pelatihan nugget jamur di Desa Gerdu Kecamatan Karangpandan Kabupaten Karanganyar. Wasana Nyata: Jurnal Pengabdian pada Masyarakat, 2(2), 35-42. https://doi.org/10.36587/wasananyata.v2i2.362 